to be unusually rich (from what little one knows of the fish populations of warm seas) he does not emphasize the danger of over-fishing tropical stocks, on the sudden introduction of efficient European methods, so strongly as the reviewer would have done. Probably this was because it was only too obvious at the time of Mr. Steven's tour that there could be no suggestion of over-fishing with the inadequate equipment at the disposal of the Colony; but a recent example of the type of trouble that must be guarded against has been the very rapid development of an over-fishing problem in the Australian shark fishery.

Mr. Steven's descriptions of existing native fishing practice are most interesting, and must be of great value to those about to undertake similar tasks in the Colonies. The Clupeoids, so far as is known, withstand intensive exploitation better than groundfish, and here development of the bonga fishery could probably proceed a very long way without danger to the stocks.

The great difficulties of preservation, processing and storage of fish in a climate which is very humid as well as hot should be more clearly visualized by all concerned in such matters (as, for example, those responsible for fixing the price of ice). The demon. stration that dehydration may give better value than canning for local purposes amounts to a challenge to the technicians to devise economic means for the large-scale dehydration of fish under the most adverse climatic conditions.

The biologist will follow the report more easily after reading the very brief account of the principal food-fishes of the area, giving scientific as well as local names, in one of the previous Government publications by Hornell ${ }^{1}$, to whose pioneer work Mr. Steven refers in his introduction. That so long an interval elapsed between Hornell's report and $\mathrm{Mr}$. Steven's appointment to follow it up is most regrettable.

T. J. HART

${ }^{1}$ Sierra Leone Studies, 14 (1929).

\section{CHEMICAL INDUSTRIES IN SCOTLAND}

\begin{abstract}
$T$ HE report of a committee appointed in May 1945 by the Scottish Council on Industry (20 George Street, Edinburgh. Pp. 39. 2s.) to inquire into the present conditions and post-war prospects of the chemical industries of Scotland and to recommend action to the Scottish Council is based on a survey made in 1945-46, and its publication has been considerably delayed. The section dealing with research has been rewritten; but the main recommendations and findings of the Committee remain unchanged in spite of the delay. The Committee made no attempt to define a chemical industry but limited the report to those industries covered under the various sections of British Chemical Abstracts $B$, excluding, however, those sections such as iron and steel, metallurgical industries and fuel, which were being studied elsewhere. Figures quoted in the sppendix show that so far as explosives are concerned the proportion of operatives employed in Scotland is well above that calculated on a United Kingdom population basis, while in the chemical industry in general the proportion is well below this figure. The Committee, however, has throughout taken the view that Scotland cannot be treated as a separate entity
\end{abstract}

when industrial development is under consideration. It has endeavoured to take a broad view and believes that any expansion of chemical industry in Scotland would have beneficial repercussions on the national economy of the whole of Britain. It also urges that a survey of an industry which so markedly depends on research involves consideration of the research facilities available in Scotland at present.

A survey of research facilities constitutes an important section of the report. This survey leads the Committee to believe that there is scope for a much more intensive application of research to problems of particular importance to Scotland, and that much of this research is of a kind which might properly be undertaken by a Government laboratory or by a research association. The principal recommendation of the report is, in fact, the formation of a chemical research committee, with representatives from industry, academic institutions and existing research associations, to formulate the problems of chemical research and development which require investigation to meet Scottish needs, to survey the facilities available for their investigation and to make recommendations for extending those facilities where required. Next, the Committee concludes that many firms have been, and still are, suffering from a shortage of labour and sometimes of technological skill. The diversity of the operations required of the workman in any manufacturing chemical process demands a high quality of labour, and on this point a conference is recommended between representatives of the Ministry of Labour and of the chemical manufacturers. Furthermore, chemical manufacturers on the whole do not yet appreciate the advantages to be derived from more adequate scientific control of chemical operations; and the Committee also recommends that their attention should be directed to the large number of graduates in pure and applied science who qualify at the Scottish universities and technical colleges every year, only ten per cent of whom at present find employment in Scotland.

Extension of the work of the Geological Survey so as to accelerate the rate of progress is recommended, and this should be given wider publicity. Indigenous raw materials such as limestone, quartz, felspar and baryta should be critically examined by the suggested chemical research committee and industrialists with the view of their utilization in new chemical development, and steps should be taken to bring the possibilities of chemical manufacturing development under the North of Scotland hydro-electric schemes before the industry. The refining and cracking of crude mineral oil in Scotland should be extended considerably and coupled with a more exhaustive utilization of coal tar as a source of chemicals. Further exploration of the potentialities of such processes as the Robinson-Brindley or the FischerTropsch for organic synthesis is also recommended. Stress is laid on the importance of a substantial reduction in the cost of coal and of easing the situation in regard to Government control of raw materials and housing. Conditions for expansion of export trade are regarded as good, but conference with shipping interests is recommended on measures to avoid the burden on manufacturers caused by the tendency to transfer Scottish manufactured material to southern ports for shipment abroad.

In regard to particular industries, the Committee hopes that the newly formed Coal Tar Research Association will find a place within its organisation for a section operating in Scotland where, owing to 
differences in coal and methods of carbonization, special problems have to be tackled; and also that the enormous post-war demand for all types of glass will be met in part by a general expansion of the Scottish industry. Scotland should also have a considerable share in the expansion of the dyestuffs industry ; but the future of the papermaking industry in Scotland is bound up with the renewed importation of esparto grass and wood pulp. The development in Scotland of viscose, other types of rayon, or entirely new fibres from vegetable protein or alginic acid, must depend entirely upon economic factors, but special attention is directed to glass fibre. There appears to be room for a steady expansion of the rubber industry in Scotland generally, in addition to developing the export market, and it is strongly urged that actual manufacture of synthetic resins should be established in Scotland. The extraction of natural drugs could well be expanded in view of the great opportunities for export, and synthetic vitamins should find a place in the well-established fine chemical industry.

\section{FORTHCOMING EVENTS}

(Meetings marked with an asterisk * are open to the public)

Monday, July 5-Friday, July 9

IRISH Chumical Association (in the Department of Chemistry, University College, Dublin), at 10 a.m.-Summer School in Chemistry.

Tuesday, July 6

Society of Chemical Industry, Plastios Grodp (at Manson House, 26 Portland Place, London, W.1), at 6.30 p.m. - 16th Annual acteristics and Chemical Structure of Cellulose Derivatives".

\section{Wednesday, July 7}

BRITISh SOCIETY FOR RESEARCH ON AGEING (at the Royal Society of Medicine, 1 Wimpole Street, London, W.1), at 11 a.m.-Conference."

Thursday, July 8

SocIety For ENDocrinology (in the Clinical Lecture Theatre, Middlesex Hospital Medical School, London, W.1), at 5 p.m.-Prof. Edwin B. Astwood : "Recent Advances in the Physiology of the Fdwin B. Astwood

Thursday, July 8-Saturday, July 10

Institrote of Physics, Manchester and District BRanch (in the Physics Department, The University, Oxford Road, Manchester). -Conference on "Semiconductors and their Applications".

Thursday, July 8

At 2 p.m.- "The Physics of Semiconductors".

Friday, July 9

At 9.30 a.m.- "Industrial Developments" ; at 2 p.m.- "Applications".

Saturday, July 10

At 9.30 a.m.-Informal Discussions, Demonstrations and Exhibits.

\section{APPOINTMENTS VACANT}

APPLICATIONS are invited for the following appointments on or before the dates mentioned

SCIENTTFIC OFFICER IN THE Chrmical RESEARCH DIVISION of the Ministry of Agriculture-The Assistant Secretary (Establishment), Ministry of Finance, Stormont, Belfast (July 9)

Assistant KEEPER (Class II)-The Director, The London Museum, James's, London, S.W.1 (July 9)

ENTOMOLOGIST to work on the biology and control of the Pea Aphis, and an ENTOMOLOGIST to assist with investigations on the biology and control of the Pea Moth and to work on the development

SENIOR OBSERVER and a JUNIOR OBSERVER-The Director, The Observatories, Cambridge (July 10).

assistant Plant Physiologist, Assistant Pomologists (2), and an ORGANIC CHEMIST for fruit products investigations, at the Long Ashton Research Station-The Secretary and Registrar, The University. Bristol (July 10)

ASSISTANT LECTURER IN ZOOLOGX-The Registrar, The University, Leeds 2 (July 10).

LABORATORY ASSISTANT (Grade II) IN THE DEPARTMRNT OF PHYSICS The Secretary, Bedford College for Women, Regent's Park, London, N.W.1 (July 10)
SENIOR LFCTURERS OF LECTURERS (2) IN THE DEPARTMENT OF EngINEERING -The Registrar, The University, Manchester 13 (July 10) PUBIIC ANALYST-The Town Clerk, Town Hall, Bolton, endorsed 'Public Analyst' (July 10).

Lecturer IN THeoremind Physias-The Registrar, King's College, Strand, London, W.C.2 (July 12)

LECTURER IN ARCHAOLOG $\mathrm{Y}$ - The Secretary, Queen's University, Belfast (July 13)

ASSISTANT IN GEOGRAPHY-The Secretary of University Court, The University, Glasgow (July 15).

Senior Leoturer or Lecturfar in Theoretical Physics-The Registrar, The University, Manchester 13 (July 17).

SENIOR RESEAROH OFFICER Or RESEAROH OFFICER (Ref. No. 1768) to undertake research into the chemical composition of Australian pasture plants, a RESEAROH OFFIOER-Ecology (Ref. No. 1769)to undertake rearch on pasture ecology, and a RusEakCH OFFIOE. -Agrostology (Ref. No. 1770) to conduct research into the establish ment and management of sown pastares, Division of Plant Industry, Canberra-The Secretary, Australian Scientiflc Research Liaiso Office, Africa House, Kingsway, London, W.C.2, quoting appropriate Ref. No. (July 24).

CHIEF CHExIST, and a RESEAROH OFFTCER for enzyme chemistry, physical chemistry, $\bar{X}$-Ray crystallography, and infra-red spectro scopy - The Secretary, Wool Industries Research Association, Torridon, Leeds 6 (July 24 )

SENIOR ANALYST, an ANALYST, and an ANALYST (Biochemist), in the City Analyst's Department -The Town Clerk, Municipal Buildings, Dale Street, Liverpool, with the appropriate endorsement (July 26). Mechanical ENGINmers (3, Principal Scientific Officer grade) in the Royal Naval Scientifle Service, for $(a)$ design and developmen of torpedoes, $(b)$ work on small control mechanisms, and $(c)$ work requiring a sound knowledge, both practical and theoretical, of steam generating plant and prime movers-The Secretary, Civil Service Commission, Scientific Branch, 27 Grosvenor Square, London, W.1 quoting No. 2186 (July 31).

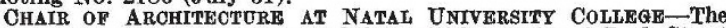
Secretary, Universities Bureau of the British Empire, 8 Park Street London, W.1. (July 31).

HEAD OF THE METALLURG DIVISION at the A tomic Energy Research Establishment-The Secretary, Civil Service Commission, Scientific Branch, 27 Grosvenor Square, London, W.1, quoting No. 2184 (July 31) ChaIr OF ChemistrY - The Secretary, The University, Aberdeen (July 31).

CHAIR OF PHYSIOS in the University of Adelaide-The Registrar, The University, Adelaide, South Australia (August 15).

Mnchanical GNGINEERS, PhYsicists or METALLURGIsts for research on mechanical working problems generally, including rolling, drawin and forging, and MECHANICAL ENGINEFRS to assist in research on mechanical working problems generally in the Metal Flow Research Laboratory-The Personnel Officer, British Iron and Steel Research Association, 11 Park Lane, London, W.1, endorsed 'Metal Flow'.

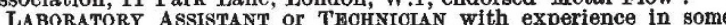
field of biological laboratory work, and a SPECIAL HISTOLOGICA

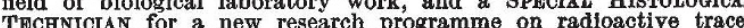
elements-The Professor of Zoology, The University, Bristol.

Gonts-The Professor of Zoology, The University, Bristol. GOVERNMENT CHEMIST in the Medical Department of the Gold Street, London, S.W.1.

TECHNICAL ReSEarch Assistant by the Professor of PhysiologyThe Secretary, King's College of Household and Social Science, Campden Hill Road, London, W.8.

SOIRNTIFIC OFFICERS and EXPERIMENTAL OFFICERS in Ministry of Supply Establishments concerned with the whole fleld of scientifle research for the Services, for Civil Aviation and for a variety of industrial purposes, in the fields of : Chemistry (Ref. F.355/48) industrial purposes, in the fields of : Chemistry (Ref. F.355/48), Biochemistry, Physiology, Pharmacology (Ref. G.184/48), AeroGynamics (Ref. A.160/48), Aircraft Structural Theory (Rer. C.301/48) Gas Turbines (Ref. C.299/48), Physics (Ref. A.159/48), Radar (Ref, A.161/48), Aircraft Instrumentation (Ref. C.300/48), Metallurgy nical and Scientific Register (K), York House, Kingsway, London,

W.C.2.

CHEMrst with research experience preferably, though not necessarily, in fleld of protein flbres-The Director, British Cotton Industr Research Association, Shirley Institute, Didsbury, Manchester.

SENIOR TROHNOLOGIST-The Secretary, British Rayon Research Association, Bridgewater House, 58 Whitworth Street, Manchester 1 BIOcHEMisT (non-medical) - The Secretary-Superintendent, County Hospital, Lincoln

Assistant TEchinician IN THE Zoology DEPARTMENT-The Registrar, University College, Southampton.

LECTURER IN LIVHSTOCK HUSBANDRY-The Principal, Harper Adams Agricultural College, Newport, Shropshire.

SENIOR LECTURER, and a LEOTURER, IN PHYSICs, at the University of Otago, Dunedin-The High Commissioner for New Zealand, 415 Strand, London, W.C.2.

STATISTroinNs in the newly created Statistical Department of the Government of Nigeria-The Director of Recruitment, Colonial Service, 15 Victoria Street, London, S.W.1.

\section{REPORTS and other PUBLICATIONS (not included in the monthly Books Supplement)}

Great Britain and Ireland

Physical Society. Report on Colour Terminology. By a Committet of the Colour Group. Pp. iv +56 . (London: Physical Society, 1948. 78. net.

A Description of Ordnance Survey Small Scale Maps. Pp. $v+21+18$ plates. (Chessington: Ordnance Survey Office, 1947.) 18. $6 d$. [135 A Description of Ordnance Survey Large Scale Maps. Pp. v $+23+0$ plates. (Chessington: Ordnance Survey Office, 1947.) 18. 6d. [135 F.P.A. Journal. Quarterly. Vol. 1, No. 1, April. Pp. 28. (London:
[185 